\title{
PENERAPAN MODEL PEMBELAJARAN PROJECT BASED LEARNING (PjBL) PADA KOMPETENSI DASAR MELAKUKAN DASAR PENGAWETAN PADA OLAHAN SUSU SEGAR
}

\author{
Implementation of Project Based Learning Model in Basic Competence of \\ Perform Basic Preservation On Fresh Milk Process
}

\author{
Lia Liawati ${ }^{1}$, Sri Handayani', Dwi Lestari Rahayui ${ }^{2}$ \\ 1,2 Program Studi Pendidikan Teknologi Agroindustri, \\ Fakultas Pendidikan Teknologi dan Kejuruan, Universitas Pendidikan Indonesia \\ E-mail: srihandayani@upi.edu
}

\begin{abstract}
ABSTRAK
Penelitian ini bertujuan untuk mengetahui keterlaksanaan sintak dan hasil belajar siswa dari penerapan model pembelajaran Project Based Learning pada kompetensi dasar melakukan dasar pengawetan. Metode penelitian yang digunakan adalah Penelitian Tindakan Kelas yang dilakukan dalam 3 siklus. Setiap siklus terdiri dari perencanaan, pelaksanaan, pengamatan, dan refleksi. Objek penelitian ini adalah peserta didik kelas X TPHP 3 jurusan Teknologi Pengolahan Hasil Pertanian SMK Negeri 1 Kuningan. Hasil belajar siswa diukur menggunakan tes objektif (pre-test dan post-test), lembar observasi sikap, lembar penilaian keterampilan, lembar observasi proses pembelajaran, dan wawancara. Model pembelajaran Project Based Learning $(\mathrm{PjBL})$ terlaksana dengan baik. Hasil penelitian menunjukkan adanya peningkatan hasil belajar siswa. Hal ini ditunjukkan oleh: (1) keterlaksanaan proses pembelajaran berjalan dengan sangat baik, (2) ketercapaian KKM pada aspek kognitif yaitu $76 \%$ pada siklus 1, $88 \%$ pada siklus II, dan $100 \%$ pada siklus III, (3) rata-rata nilai afektif pada indikator spiritual, jujur, tanggung jawab, disiplin, percaya diri, dan sopan santun mengalami peningkatan pada siklus I ke siklus II dan III, (4) rata-rata nilai psikomotorik siswa termasuk ke dalam katagori "sangat baik".
\end{abstract}

Kata Kunci : Project Based Learning (PjBL), hasil belajar, kompetensi dasar melakukan dasar pengawetan.

\begin{abstract}
The aims of the research is to know the syntax implementation and learning student learning outcomes from applying the Project Based Learning model on base competence of do basic preservation. This research used is Classroom Action Research method which has done in 3 cycles. Every cycle consists of planning, execution, observation, and reflection. The objects of this reseach are students of X TPHP 3 class major of Technological Processing Agricultural Product in $1^{s}$ Vocational Hight School of Kuningan. learning outcomes are measured by using objective test (pre-test and post-test), attitude assessment sheet, performance assessment sheet, and learning process observation sheet. The Based Learning (PjBL) learning model was well done. The result of this research show that student learning outcomes were increased. Thet were showed by: (1) the implementation of learning process is very good (2) KKM achievement on cognitive aspect is $76 \%$ in cycle 1, $88 \%$ in cycle II, and 100\% in cycle III, (3) average the affective assesment of spiritual, honest, responsible, disciplined, confident, and courteous indicators have increased in cycle I to cycle II and III, (4) the students' psychomotor assesment is included in the "very good" category.
\end{abstract}

Keywords: Project Based Learning, learning outcomes, base competence of perform basic preservation 


\section{PENDAHULUAN}

SMKN 1 Kuningan telah menerapkan kurikulum 2013. Untuk memenuhi ketercapaian Kompetensi Inti dan Kompetensi Dasar pada kurikulum 2013, proses pembelajaran diperkuat dengan pendekatan ilmiah (scientific approach/pendekatan saintifik) yang didukung dengan model pembelajaran berbasis penyingkapan/penelitian (discovery/inquiry learning), model pembelajaran yang menghasilkan karya (project based learning) dan model pembelajaran berbasis pemecahan masalah (problem based learning).

Model pembelajaran yang biasanya digunakan pada semua mata pelajaran untuk kelas $X$ SMKN 1 Kuningan yaitu model inquiri. Kelemahan dari pembelajaran dengan model inquiri yaitu sulitnya mengontrol kegiatan dan keberhasilan siswa dan sulit dalam merencanakan pembelajaran karena terbentur dengan kebiasaan siswa dalam belajar. Bagi siswa SMK, penggunaan model inquiri kurang cocok terutama untuk meningkatkan kompetensi di ranah keterampilan. Model pembelajaran inquiri sulit diterima oleh siswa sehingga keberhasilan siswa dalam pembelajaran tidak tercapai. Hal tersebut ditunjukkan oleh masih banyak siswa yang nilainya belum mencapai kriteria ketuntasan milimal (KKM) yaitu sebanyak $60,71 \%$ pada mata pelajaran Dasar Proses Pengolahan Hasil Pertanian dan Perikanan (sumber : dokumen SMKN 1 Kuningan).

Salah satu model pembelajaran inovatif yang berpusat pada siswa dan menempatkan guru sebagai motivator dan fasilitator, dimana siswa diberi peluang bekerja secara otonom mengkontruksi belajarnya salah satunya adalah pembelajaran Project Based Learning ( $\mathrm{PjBL}$ ) atau jika dalam bahasa Indonesia disebut pembelajaran berbasis proyek. Menurut Titu (2015), dalam pembelajaran berbasis proyek, peserta didik terdorong lebih aktif dalam belajar dan menghasilkan produk nyata yang dapat mendorong kreativitas siswa agar mampu berpikir kritis. Hal yang sama ditunjukkan oleh Saputra (2013) dimana terjadi peningkatan keaktifan siswa ranah psikomotorik dari siklus I hingga siklus II dengan menggunakan model pembelajaran PjBL. Penelitian yang dilakukan Gede (2015) juga menunjukan bahwa terjadi peningkatan hasil belajar ditandai dengan adanya perbedaan rata-rata nilai pretest dan posttest dari 70.4 menjadi 75.07 . Hasil tersebut menunjukkan bahwa penerapan model Project Based Learning dapat meningkatkan hasil belajar.

Pada kompetensi dasar melakukan dasar pengawetan, model pembelajaran Project Based Learning $(\mathrm{PjBL})$ sangat sesuai digunakan karena pada penelitian ini menghasilkan karya pengawetan susu segar berupa permen susu. Selain hal tersebut, Project Based Learning (PjBL) digunakan untuk mengikuti model pembelajaran kurikulum 2013 dan kurikulum di SMKN 1 Kuningan. Materi pokok pada kompetensi dasar melakukan dasar pengawetan yang akan dipraktikan pada kompetensi dasar ini yaitu dasar pengawetan dengan penggulaan. Susu segar banyak terdapat di Kecamatan Cigugur, Kabupaten Kuningan yaitu daerah di sekitar SMKN 1 Kuningan. Susu segar temasuk bahan pangan perishable food atau bahan pangan yang mudah rusak sehingga salah satu cara mengewetkannya dengan diolah menjadi permen susu.

Tujuan penelitian ini adalah (1) untuk mengetahui proses penerapan model pembelajaran Project Based Learning (PjBL) pada kompetensi dasar melakukan dasar pengawetan pada olahan susu segar menjadi permen susu. (2) untuk mengetahui hasil belajar siswa dilihat dari sikap, pengetahuan, dan keterampilan dengan menerapkan model pembelajaran Project Based Learning (PjBL) pada kompetensi dasar melakukan dasar pengawetan pada olahan susu segar menjadi permen susu. (3) untuk mengetahui sintaks model pembelajaran Project Based Learning (PjBL) yang sesuai dengan kompetensi dasar melakukan dasar pengawetan pada olahan susu segar menjadi permen susu.

\section{METODE}

Desain penelitian yang digunakan adalah Penelitian Tindakan Kelas (Classroom Action Research). Berdasarkan Kemmis dan Mc. Taggart (1999) siklus PTK terdiri dari empat komponen, keempat komponen tersebut, yaitu: (1) perencanaan, (2) aksi/tindakan, (3) observasi, dan (4) refleksi yang dilakukan sebanyak 3 siklus. Sampel yang digunakan pada penelitian ini adalah Program Studi Keahlian Agroindustri tahun ajaran 2016-2017 sebanyak 28 orang siswa kela X TPHP 3. 
Instrumen yang digunakan untuk mengumpulkan data dalam penelitian ini diantaranya tes objektif dan non tes. Instrumen tes objektif berupa pre-test dan post-test yang dilakukan pada setiap siklus pembelajaran dengan masing-masing tes 15 soal pilihan ganda. Sedangkan instrumen non tes berupa pedoman observasi, yaitu: lembar pengamatan proses pembelajaran, lembar penilaian afektif siswa, lembar penilaian praktikum, dan lembar wawancara. Validasi untuk instrument tes objektif dilakukan dengan judgement ekspert oleh guru mata pelajaran TPHP, untuk mengetahui kelayakan setiap butir soal yang akan diberikan kepada peserta didik.

\section{HASIL DAN PEMBAHASAN}

\section{Keterlaksanaan Model Pembelajaran Project Based Learning (PjBL) pada Kompetensi Dasar Melakukan Dasar Pengawetan}

Implementasi model pembelajaran Project Based Learning (PjBL) dilakukan berdasarkan sintak pembelajaran yang telah dicancang oleh peneliti pada Gambar 1. Terdapat 6 tahap pembelajaran yang dilaksanakan pada proses pembelajaran dengan tiga kali pertemuan pembelajaran atau tiga siklus. Berdasarkan hasil pengamatan observer, dinyatakan bahwa keterlaksanaan proses pembelajaran sesuai RPP pada setiap siklusnya dimana setiap sintak pembelajaran dilakukan dengan baik oleh siswa maupun guru mata pelajaran.

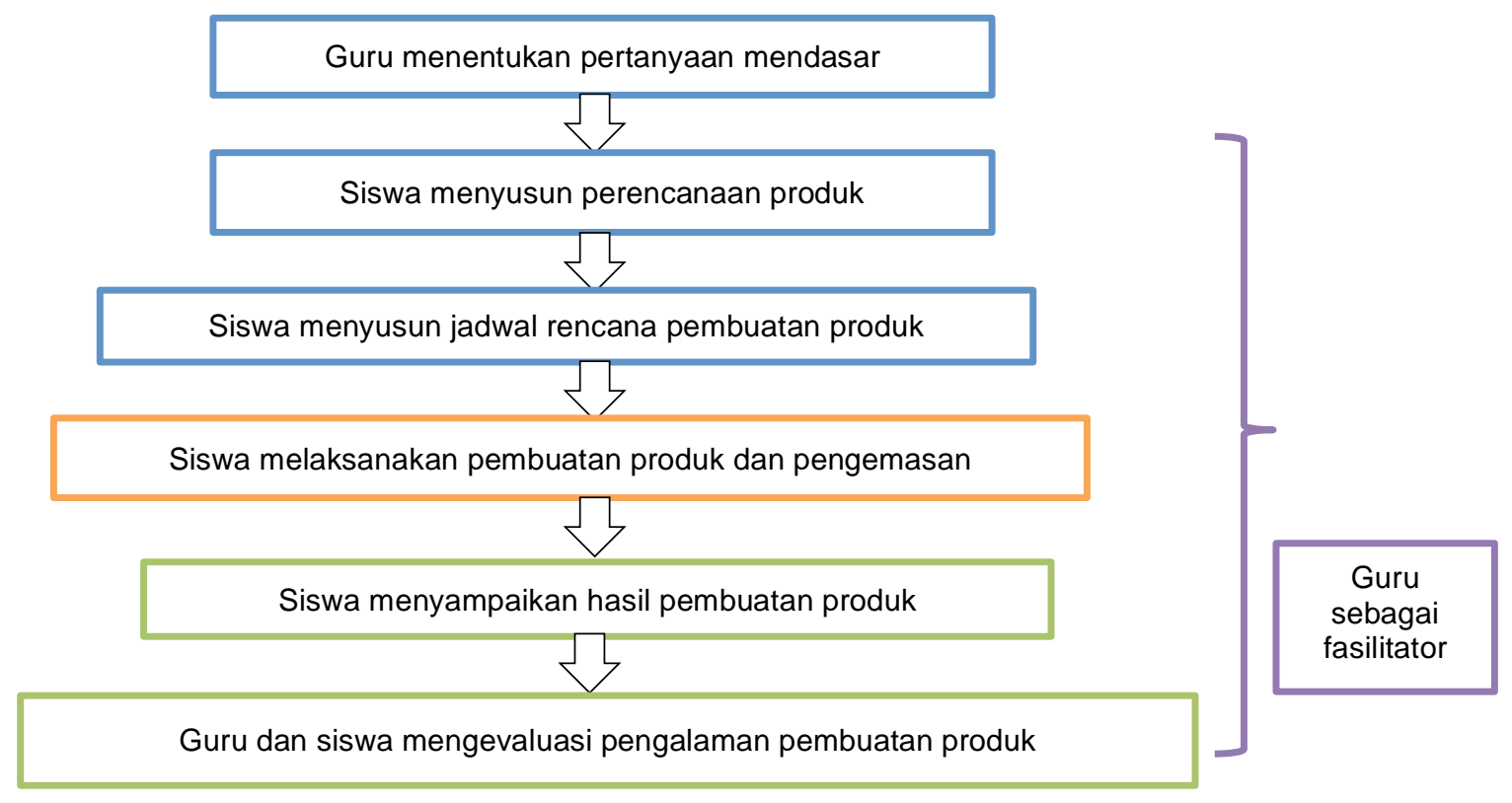

Gambar 1. Tahap-Tahap Pembelajaran Berbasis Proyek sesuai Kompetensi Dasar Melakukan Dasar Pengawetan

Berdasarkan pengamatan keterlaksanaan yang dilakukan, siswa merasakan pembelajaran Project Based Learning (PjBL) menjadi hal baru dalam proses pembelajaran yang biasanya berlangsung. Siswa menjadi lebih antusias dan aktif dalam mengikuti proses pembelajaran. Siswa merasa lebih tertarik dan menikmati proses pembelajaran yang dilakukan. Proses pembelajaran Project Based Learning (PjBL) membuat siswa lebih berpikir kreatif untuk mengkontruksi belajarnya sendiri dengan cara siswa membuat suatu project untu menghasilkan suatu produk. Hal tersebut ditandai dengan nilai pengetahuan dapat membuat daya tarik siswa untuk mengikuti proses pembelajaran. Bersesuaian dengan yang diungkapkan Trianto (2014) bahwa Project Based Learning (PjBL) adalah model pembelajaran yang melibatkan peserta didik dalam kegiatan pemecahan masalah dan memberi peluang peserta didik bekerja secara otomom mengkontruksi belajar mereka sendiri, dan puncaknya menghasilkan produk karya siswa bernilai 
dan realistik.Pelaksanaan model pembelajaran Project Based Learning (PjBL) dilakukan dengan pendekatan saintifik berdasarkan Direktorat Pembinaan SMK (2016) yang mengacu pada proses berpikir secara ilmiah yang dilaksanakan pada satu kali proses pembelajaran dalam suatu kompetensi dasar dengan tiga siklus atau tiga kali pertemuan. Adapun pendekatan saintifik yang dilakukan peneliti sebagai guru kepada peserta didik yaitu:

a) Mengamati, merupakan kemampuan awal peserta dalam mengumpulkan informasi dengan tujuan untuk dapat mengidentifikasi masalah, yang kegiatan belajarnya dilakukan dengan menanya, mengamati video pengembangan produk yang ditampilkan oleh guru, dan atau menalar terhadap materi yang dipelajari yaitu melakukan dasar pengawetan dengan metode pengulaan.

b) Menanya, siswa dapat merumuskan masalah dan atau merumuskan hipotesis, yang kegiatan belajarnya dilakukan dari mengamati (membaca buku, prosedur kerja), menanya dalam kegiatan diskusi, atau menanya pada diri sendiri maupun langsung pada orang lain (guru sebagai nara sumber, siswa lainnya) pada masing-masing kelompok yang terbentuk dengan bimbingan guru yang mendorong motivasi siswa untuk tetap aktif dan gembira hingga siswa dapat mandiri dan menjadi kebiasaan, siswa mampu membuat perencaan dan penjadwalan proyek.

c) Mengumpulkan data, siswa dapat menguji rumusan masalah dan atau hipotesis yang telah dibuat, yang kegiatan belajarnya dilakukan melalui proses uji coba (praktikum) dimulai dari kegiatan pengadaan bahan, proses produksi, pengawasan mutu produk, dan pengemasan.

d) Mengasosiasi, siswa dapat menyimpulkan hasil kajian rumusan masalah dan atau hipotesis, yang kegiatan belajarnya mengolah data dalam bentuk serangkaian aktivitas fisik dan pikiran dengan bantuan peralatan tertentu, Selanjutnya siswa menganalisis data untuk membandingkan ataupun menentukan hubungan antara data yang telah diolah dari hasil praktikum pengembangan produk dengan teori yang ada sehingga dapat ditarik simpulan dan atau ditemukannya prinsip dan konsep penting yang bermakna dalam menambah skema kognitif, meluaskan pengalaman, dan wawasan pengetahuannya.

e) Mengkomunikasikan, siswa dapat mendeskripsikan dan menyampaikan hasil praktikumnya dari kegiatan mengamati, menanya, mengumpulkan dan mengolah data, serta mengasosiasi yang ditujukan kepada orang lain baik secara lisan maupun tulisan dalam bentuk laporan praktikum dengan bantuan perangkat teknologi sederhana dan tau teknologi informasi dan komunikasi, yaitu media presentasi power point.

\section{Hasil Belajar Kognitif}

Hasil belajar ranah kognitif dengan penerapan model pembelajaran Project Based Learning (PjBL) yang telah dilaksanakan dari tiga siklus menunjukan hasil yang berbeda. Terdapat kenaikan hasil belajar ( $N$-gain) dari setiap siklus. Kenaikan hasil belajar ( $N$-gain) dari setiap siklus terlihat pada Gambar 2.

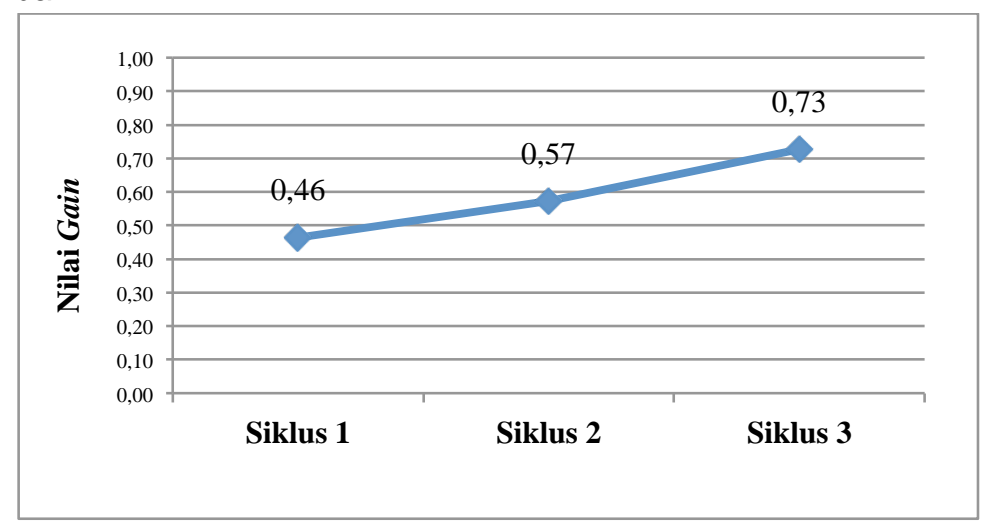

Gambar 2 Hasil belajar atau gain peserta didik dengan penerapan model pembelajaran Project Based Learning (PjBL) pada kompetensi dasar melakukan dasar pengawetan pada olahan susu segar 
Berdasarkan nilai gain yang diperoleh dari hasil belajar siswa terlihat bahwa adanya peningkatan belajar siswa dari siklus I ke siklus II dan peningkatan belajar siswa dari siklus II ke siklus III. Peningkatan nilai kognitif siswa secara signifikan terjadi setelah mengikuti proses pembelajaran dengan model Project Based Learning (PjBL).

Keberhasilan hasil belajar siswa dengan menggunakan model pembelajaran Project Based Learning (PjBL) secara umum terlihat dari ketuntasan belajar siswa. Peningkatan ketuntasan belajar siswa dari setiap siklusnya disajikan pada Gambar 3. Terlihat bahwa terjadi peningkatan siswa yang tuntas memenuhi nilai KKM yaitu 75 pada siklus I ke siklus III, yaitu ketuntasan siswa pada siklus I ke siklus II mengalami peningkatan dari 19 orang menjadi 22 orang dan ketuntasan siswa pada siklus II ke siklus III mengalami peningkatan dari 22 orang menjadi 25 orang, dimana seluruh siswa memenuhi nilai KKM pada pembelajaran siklus ke III. Hal ini sejalan dengan penelitian yang dilakukan Gangga (2013) dimana penggunaan model pembelajaran Project Based Learning PjBL dapat meningkatkan hasil belajar siswa bidang kognitif terjadi peningkatan jumlah siswa yang mencapai ketuntasan belajar pada setiap siklusnya.

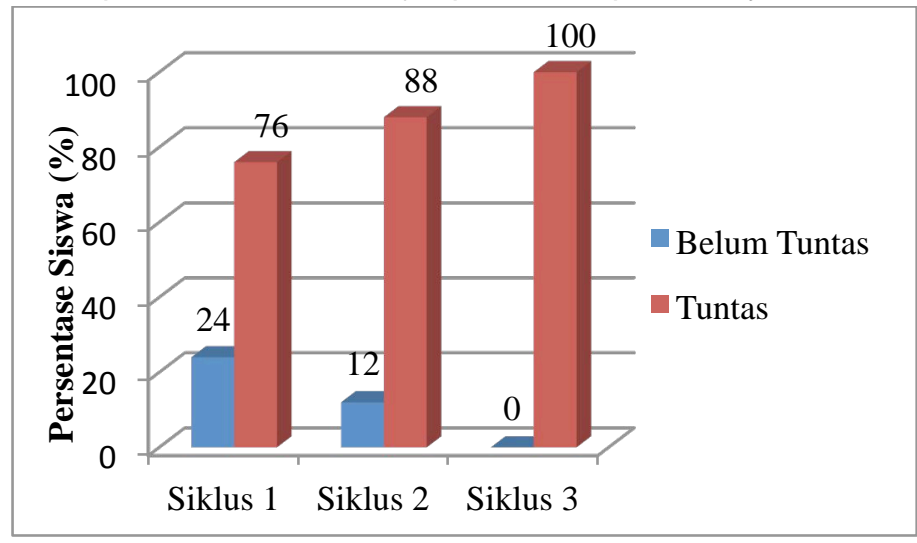

Gambar 3 Ketuntasan Pembelajaran Setiap Siklus

\section{Hasil Belajar Afektif}

Hasil belajar afektif merupakan hasil observasi sikap siswa pada penerapan model pembelajaran Project Based Learning ( $\mathrm{PjBL}$ ). Aspek sikap yang diamati yaitu spiritual, jujur, tanggungjawab, disiplin, percaya diri, dan sopan santun. Secara keseluruhan siswa memiliki sikap yang baik dan meningkat dari siklus 1 hingga 3 . Hal ini tidak terlepas dari peran guru dalam proses pembelajaran. Menurut (Gangga, 2013) guru dalam proses belajar mengajar merupakan faktor penentu dalam upaya meningkatkan mutu pembelajaran termasuk dalam membina sikap siswa. Hasil belajar afektif berkaitan dengan hasil belajar kognitif dan psikomotorik. Siswa yang memiliki sikap yang baik memiliki hasil belajar kognitif dan psikomotor yang baik. Hal ini juga sesuai dengan penelitian Gusviani (2016) bahwa pengembangan sikap spiritual dan sikap sosial mendasari pengembangan pengetahuan dan keterampilan. Adapun hasil analisis terhadap aspek sikap adalah sebagai berikut:

- Spiritual : Sikap spiritual siswa semakin lebih baik dengan semakin banyaknya siswa yang mengucapkan salam sebelum bertanya atau mengemukakan pendapat.

- Jujur : Sikap kejujuran siswa konsisten mulai dari siklus 1 hingga siklus 3. Hal ini dikarenakan sebelum melaksanakan tes guru memotivasi siswa untuk percaya akan hasil diri diri sendiri.

- Tanggungjawab : Sikap tanggung jawab siswa menjadi lebih baik dari siklus 1 hingga 3. Siswa semakin aktif berpartisipasi dalam mengerjakan proyek.

- Disiplin : Kedisiplinan siswa semakin baik dengan tidak adanya siswa yang terlambat dan mengenakan seragam sesuai hari dan ketentuan yang berlaku.

- Percaya Diri : Sikap percaya diri semakin baik pada setiap siklusnya. Siswa semakin berani tampil di depan kelas dan bertanya atau mengemukakan pendapat di depan teman-teman. 
- Sopan Santun : Siswa memiliki sikap sopan santun yang baik selama proses pembelajaran. Namun kurang telitinya pengawasan guru pada siklus 3 menyebabkan salah satu siswa tidak menyimak dan menghargai teman yang sedang menyajikan hasil pembuatan permen susu.

\section{Hasil Belajar Psikomotorik}

Ketercapaian hasil belajar siswa pada ranah psikomotor ini dinilai berdasarkan pelaksanaan praktikum dengan enam aspek penilaian, yaitu: persiapan, proses, sikap kerja, hasil, dan waktu pengerjaan.

Grafik penilaian pada ranah psikomotorik aspek persiapan kerja terdapat pada Gambar 4.

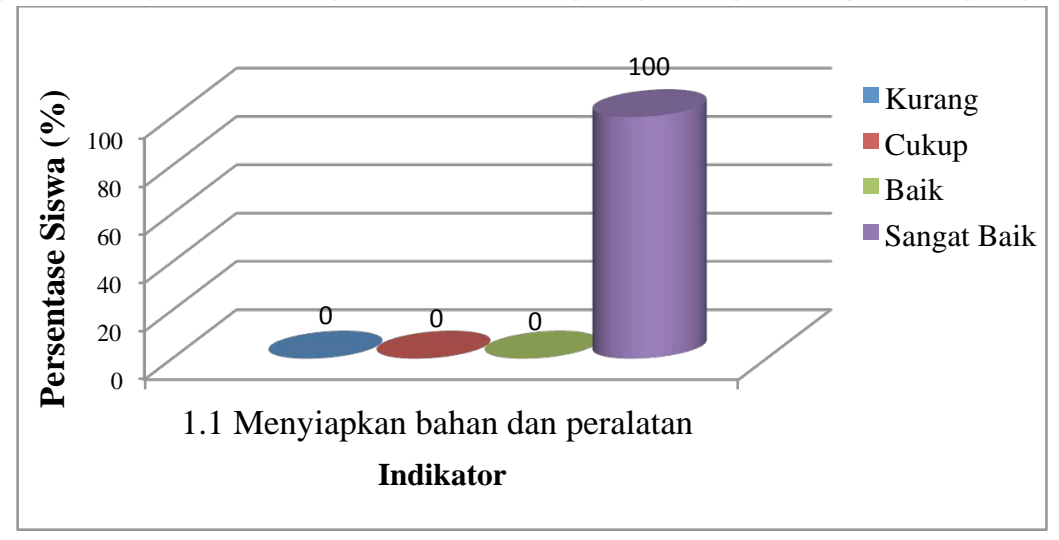

Gambar 4 Grafik penilaian psikomotorik pada aspek persiapan kerja

Pada aspek persiapan kerja semua siswa melaksanakan praktikum dengan sangat baik (100\%) yaitu mempersiapkan alat dan bahan sesuai kebutuhan, dibersihkan, dan dilakukan secara sistematis.

Hasil penilaian psikomotorik pada aspek proses (sistematika dan cara kerja) terdapat pada Gambar 10.

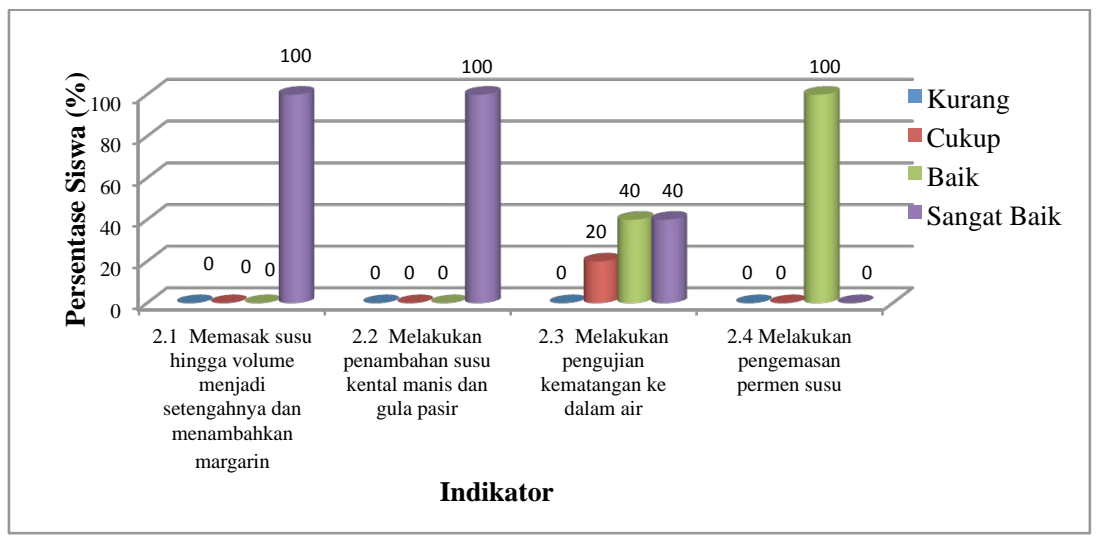

Gambar 5 Grafik penilaian psikomotorik pada aspek proses

Dari Gambar 5 Semua siswa melaksanakan proses pembuatan permen susu dengan sangat baik (100\%) pada dua indikator (2.1 dan 2.2) pencapaian yaitu susu yang digunakan memiliki warna, rasa, tekstur dan aroma yang normal. Susu dipanaskan hingga menjadi $1 / 2$ dari volume sebelumnya. Menambahkan margarin setelah susu mendidih. Selain itu mengecilkan api kompor kemudian melakukan penambahan susu kental manis 1/8 dari volume susu. Selanjutnya menambahkan gula pasir sebanyak $1 / 4$ dari volume susu.

Indikator penilaian pada subkomponen 2.3 melakukan pengujian kematangan ke dalam air yaitu dengan sudah menyediakan mangkuk yang berisi air bersih. Sebagian siswa melakukan proses dengan baik (40). Uji kematangan dengan cara meneteskan sedikit adonan ke dalam air dingin, jika terbentuk padatan yang tetap utuh saat dikeluarkan dari air, berarti pemasakan sudah 
selesai. Namun sebagaian ada juga siswa yang mendapatkan nilai baik $(40 \%)$ dan cukup baik (20\%).

Penilaian psikomotor pada subkomponen 2.4 yaitu seluruh siswa melakukan proses pengemasan dengan baik (100\%) ditandai dengan kemasan yang digunakan rapih namun tidak menggunakan label. Siswa belum mempelajari tentang label pada produk pangan sehingga produk yang dihasilkan tidak berlabel.

Grafik penilaian psikomotorik pada aspek hasil kerja terdapat pada Gambar 6.

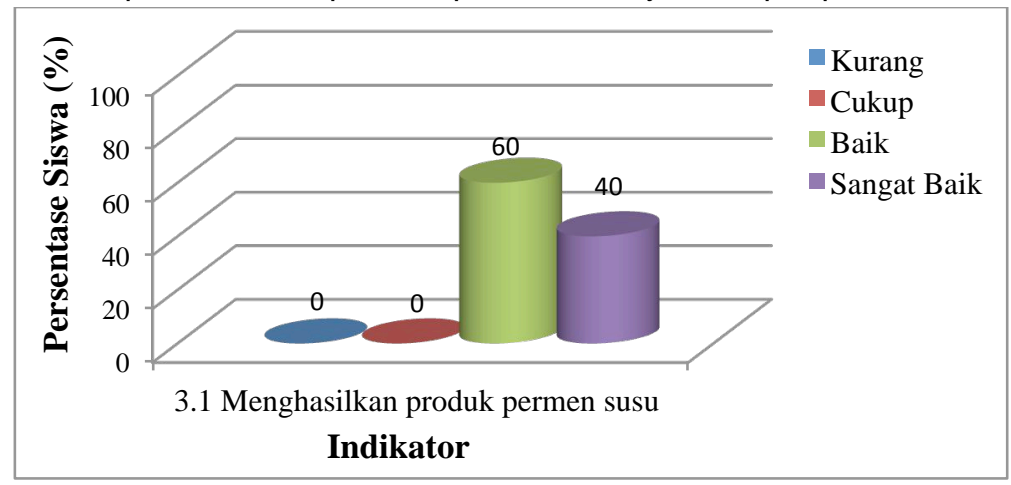

Gambar 6 Grafik penilaian psikomotorik pada aspek hasil kerja

Penilaian psikomotorik pada indikator menghasilkan produk permen susu yaitu $40 \%$ siswa melakukan praktikum dengan sangat baik. Permen susu yang dihasilkan memiliki warna, rasa, dan aroma yang normal. Namun $60 \%$ siswa melakukan praktikum dengan baik. Hal ini dikarenakan ada kelompok yang kurang mengkreasikan rasa yang dibuat. Adanya modifikasi rasa sesuai kreasi kelompok.

Penilaian psikomotorik terhadap aspek sikap kerja terdapat pada Gambar 7.

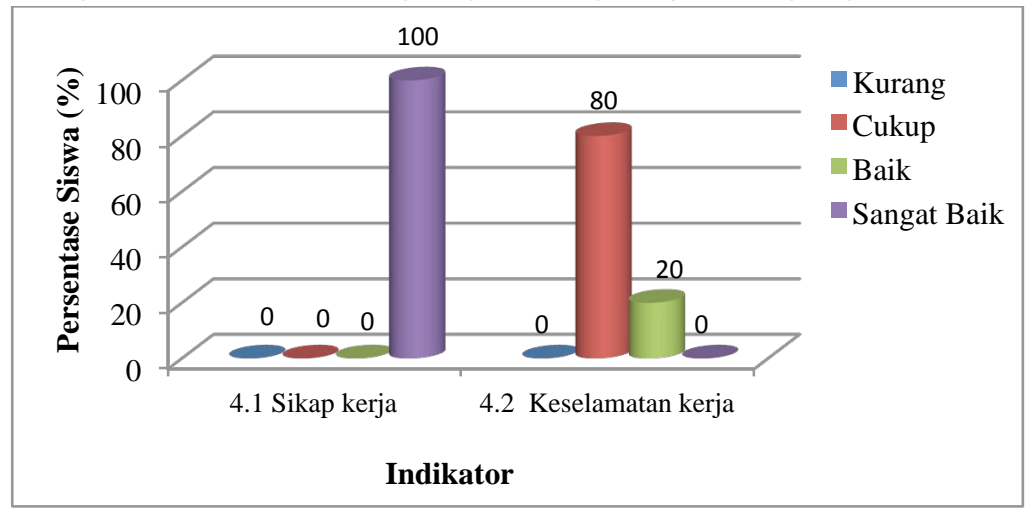

Gambar 7 Grafik penilaian psikomotorik pada aspek sikap kerja

Dari indikator 4.1 sikap kerja selama praktikum siswa mendapatkan nilai sangat baik (optimum) ditandai dengan berkonsentrasi, disiplin, bertanggungjawab, dan menjaga kebersihan.

Dari indikator 4.2 keselamatan kerja praktikum sebagian besar siswa mendapatkan nilai yang cukup, sedangkan sebagaian lainnya mendapatkan nilai baik. Hal ini dikarenakan alat keselamatan kerja (jas lab, masker, dan tutup kepala) untuk kelas X TPHP masih belum tersedia.

Penilaian terhadap waktu pengerjaan pembuatan permen susu terdapat pada Gambar 8. Dari indikator waktu penyelesaian produksi siswa mendapatkan nilai optimum. Hal ini dikarenakan dalam pembuatan permen susu semua kelompok menyelesaikan tepat pada waktunya. 


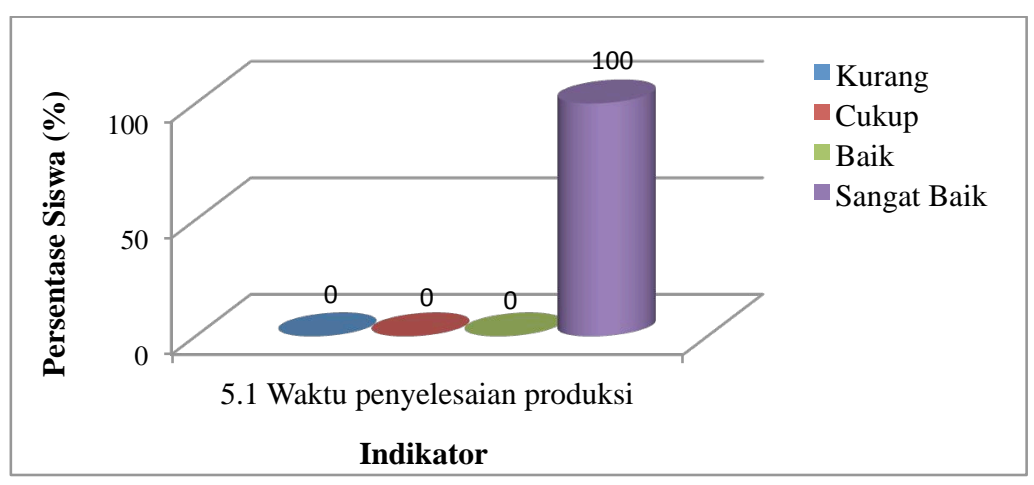

Gambar 8 Grafik penilaian psikomotorik pada aspek sikap kerja

\section{Kelebihan dan Kekurangan Model Pembelajaran Project Based Learning (PjBL) pada Kompetensi Dasar Melakukan Dasar Pengawetan}

Kelebihan Model Pembelajaran Project Based Learning (PjBL) pada Kompetensi Dasar Melakukan Dasar Pengawetan yaitu : (1) Membuat suasana lebih menyenangkan dalam proses pembelajaran, baik dalam pembelajaran di kelas, praktikum, maupun presentasi pada akhir siklus. (2) Siswa menjadi lebih terarah dalam pelaksanaan praktikum melalui perencanaan dan penjadwalan proyek yang telah dibuat. (3) Meningkatkan motivasi siswa untuk menyelesaikan proyek secara kolaboratif dan berusaha menghasilkan produk terbaik. (4) Meningkatkan rasa percaya diri dalam menyatakan pendapat di depan teman-teman melalui diskusi dan tanya jawab terutama dalam pelaksanaan presentasi. (5) Mendorong siswa untuk mengembangkan keterampilan komunikasi dan pemecahan masalah melalui pembuatan dan penyelesaian proyek. (6) Meningkatkan keaktifan siswa dalam proses pembelajaran. (7) Meningkatkan pengetahuan melalui pembelajaran mengenai dasar pengawetan metode penggulaan di kelas yang diaplikasikan dalam bentuk proyek pembuatan permen susu. (8) Meningkatkan kreativitas siswa dalam memilih alat dan bahan sesuai dengan kreasi pada perencanaan proyek sehingga bentuk dan rasa menjadi lebih beragam. (9) Meningkatkan terampilan mengelola sumber melalui praktik mengorganisasi proyek pembuatan permen susu, membuat alokasi waktu, dan sumber lain seperti jenis kemasan yang cocok digunakan untuk mengemas permen susu.

Kelemahan Model Pembelajaran Project Based Learning (PjBL) pada Kompetensi Dasar Melakukan Dasar Pengawetan yaitu (1) Diperlukan perencanaan yang matang dan alokasi waktu yang lama terutama dalam penyusunan perencanaan proyek yang dilakukan. (2) Diperlukan asisten laboran untuk memonitoring siswa dalam pelaksanaan praktikum.

Berdasarkan hasil wawancara yang dilaksanakan sebelum dan sesudah pelaksanaan pembelajaran dengan model pembelajaran Project Based Learning (PjBL) pada Kompetensi Dasar Melakukan Dasar Pengawetan, secara keseluruhan siswa lebih menyukai proses pembelajaran berbasis proyek dibandingkan dengan model pembelajaran inquiri yang digunakan sebelumnya. Siswa merasa proses pembelajaran yang dilakukan menyenangkan sehingga lebih memahami materi pelajaran yang diberikan dengan mengaitkan dengan kehidupan sehari-hari. Selain itu, pemahaman materi diperkuat dengan adanya praktikum berbasis proyek pembuatan permen susu. Pada proses evaluasi pengalaman siswa lebih aktif dan percaya diri untuk bertanya dan mengemukakan pendapat dihadapan teman-teman. Siswa menyenangi proses praktikum karena dapat bekerja bersama-sama untuk menyelesaikan proyek sehingga terasa lebih ringan, namun siswa merasa kesulitan dalam beberapa tahap penting pembuatan permen susu, diantaranya dalam menentukan kematangan permen susu dan proses pencetakan.

\section{Sintak Model Pembelajaran Project Based Learning (PjBL) yang paling cocok digunakan pada Kompetensi Dasar Melakukan Dasar Pengawetan}

Dalam penerapannya sintak pada Gambar 1 masih terdapat kekurangan sehingga ada penambahan sintak pada siklus 1 dan 2. Dari hasil penelitian pada siklus 1 sebelum adanya 
penentuan pertanyaan mendasar ditambahkan sintak pemberian materi dengan pendekatan saintifik (mengamati dan menanya) karena di kelas $x$ masih penyampaian materi terlebih dahulu. Ditambahkan sintak memonitoring hasil perencanaan proyek dengan pendekatan saintifik (mengumpulkan data / informasi) karena guru berperan sebagai mentor selama pelaksanaan pembuatan proyek tidak hanya pada siklus 2 saja. Pada siklus 2 sintak memonitoring peserta didik dengan pendekatan saintifik (mengumpulkan data / informasi) ditambahkan dengan melaksanakan pembuatan produk. Setelah itu ditambahkan penyusunan laporan proyek (asosiasi/mengkomunikasikan) agar lebih rinci dan lebih mudah dalam penerapannya. Untuk siklus 3 tidak ada penambahan sintak.

\section{KESIMPULAN}

1. Model pembelajaran Project Based Learning (PjBL) terdiri 6 sintak yaitu menentukan pertanyaan mendasar, menyusun perencanaan produk, menyusun jadwal pembuatan produk, melaksanakan pembuatan produk dan pengemasan, menguji hasil, dan evaluasi pengalaman yang terbagi menjadi 3 siklus terlaksana dengan sangat baik.

2. Terjadi peningkatan hasil belajar siswa kelas X TPHP 3 dengan menggunakan model pembelajaran Project Based Learning (PjBL) pada kompetensi dasar melakukan dasar pengawetan. Hal tersebut ditunjukkan oleh:

a. Hasil belajar ranah kognitif Hasil belajar ranah kognitif terjadi peningkatan ketuntasan belajar dan $n$-gain.

b. Hasil belajar ranah afektif Hasil belajar pada ranah afektif terdiri dari aspek spiritual, jujur, tanggung jawab, disiplin, percaya diri, dan sopan santun yang semakin baik pada setiap siklusnya.

c. Hasil belajar ranah psikomotor

Hasil penilaian psikomotorik terdiri dari penilaian terhadap persiapan kerja mendapatkan nilai sangat baik, proses (sistematika dan cara kerja) mendapatkan nilai sangat baik, hasil kerja mendapatkan nilai yang baik, sikap kerja mendapatkan nilai yang baik, dan waktu penyelesaian mendapatkan nilai sangat baik.

3. Sintak model pembelajaran Project Based Learning (PjBL) yang sesuai dengan kompetensi dasar melakukan dasar pengawetan yaitu:

- Pada siklus 1 pemberian materi pelajaran kurang maksimal dan dalam proses pembuatan perencanaan siswa membutuhkan bimbingan sehingga ditambahkan dua sintak yaitu guru menyampaikan materi pada awal pembelajaran (mengamati dan menanya) dan memonitoring hasil perencanaan produk (mengumpulkan data/informasi). Sintak pada siklus 1 menjadi 5 dengan susunan guru menyampaikan materi, guru memberikan pertanyaan mendasar, siswa menyusun perencanaan, menyusun jadwal pembuatan produk, dan guru memonitoring hasil perencanaan produk.

- Pada siklus 2 siswa membutuhkan bimbingan dalam setiap langkah pengerjaan proyek dan membutuhkan waktu untuk mengisi lembar pengamatan sehingga ditambahkan 2 sintak yaitu guru memonitoring pelaksanaan pembuatan produk dan pengemasan serta siswa mengisi lembar pengamatan dan menyusun laporan praktikum. Sintak pada siklus 2 menjadi 3 yaitu siswa melaksanakan pembuatan produk dan pengemasan, guru memonitoring pelaksanaan pembuatan produk dan pengemasan, dan siswa mengisi lembar pengamatan dan menyusun laporan praktikum.

- Pada siklus 3 tidak ada penambahan atau pengurangan sintak. 


\section{DAFTAR PUSTAKA}

Gangga, J. (2013) Penerapan Model Pembelajaran Project Based Learning Dalam Peningkatan Motivasi dan Hasil Belajar. Artikel Universitas Negeri Padang. HIm. 1-21.

Gede, S. (2015) Penerapan Model Project Based Learning Untuk Meningkatkan Hasil Belajar Siswa Pada Pelajaran Penerapan Rangkaian Elektronika Kelas Xi Tav 1 Di Smk Negeri 3 Singaraja. Jurnal PTE Universitas Pendidikan Ganesha, (4) 1. HIm. 1-10.

Gusviani, E. (2016) Analisis Kemunculan Sikap Spiritual Dan Sikap Sosial Dalam Kegiatan Pembelajaran Ipa Kelas IV SD Yang Menggunakan KTSP dan Kurikulum 2013. Jurnal Pendidikan Dasar UPI, 8 (1). HIm. 96-100.

Saputra, R.D. (2013) Penerapan Metode Pembelajaran Project Based Learning (PjBL) Untuk Meningkatkan Prestasi Belajar Kompetensi Computerised Aided Design (Cad) Dengan Software Inventor Siswa Kelas Xi Teknik Pemesinan Di Smk Negeri 2 Klaten. Skripsi, Program Studi Pendidikan Teknik Mesin, Fakultas Teknik, Universitas Negeri Yogyakarta.

Titu, M. (2015) Penerapan Model Pembelajaran Project Based Learning (PjBL) Untuk Meningkatkan Kreativitas Siswa Pada Materi Konsep Masalah Ekonomi. Jurnal Prosiding Seminar Nasional. HIm. 176-186.

Widyantini, T. (2014) Penerapan Model Project Based Learning (Model Pembelajaran Berbasis Proyek) dalam Materi Pola Bilangan Kelas VII .Artikel, Pusat Pengembangan Dan Pemberdayaan Pendidik dan Tenaga Kependidikan (PPPPTK) Matematika 